\title{
How Middle School Curriculum in Chongqing Portrays Chinese Socialism
}

\author{
Peter Miller \\ University of Windsor
}

\begin{abstract}
This project is contextualized in Shijing $\mathrm{Xu}$ and Michael Connelly's (20132020) SSHRC Partnership Grant Project, Canada-China Reciprocal Learning in Teacher Education and School Education. The goal of the SSHRC Partnership Grant Project is to compare Canadian and Chinese education in such a way that the cultural narratives of each provide frameworks for understanding and appreciating educational similarities and differences (Xu \& Connelly, 2017). The overall goal centers on reciprocal learning in teacher education between Canada and China. Xu and Connelly (2017) emphasize research that focuses on centering the voices of teachers in both Canada and China. This work seeks to help the project by providing data on China's politics curriculum to create a better understanding of China's education system, and to gain some insight into the hopes and dreams of Chinese politics teachers.
\end{abstract}

\section{Learning about Chinese Marxism Through the Reciprocal Learning Program}

I came to this research project as a Marxist from Canada who is interested in expanding development in China as well as improving living conditions for Chinese people. When I started in the Bachelor of Education program at the University of Windsor, I did not know about the Reciprocal Learning Program and the opportunity it provides to teacher candidates to experience education in China. However, I was informed about the program in my first week of study when I met with Dr. Xu. When she suggested I could study Chinese Marxism education, I was thrilled by the opportunity, especially to learn more about teaching in a country led by the Communist Party of China.

You may ask, why is a Canadian interested in Marxism and the Communist Party of China? I began to seriously study Marxism in my first year of undergrad when I joined the Young Communist League of Canada - Guelph club. Before I joined, I was, and continue to be active in, campaigns for post-secondary education to be tuition fee free. My role in this activism included 
traveling to Quebec for two weekends to support the Quebec student strike in 2012, where Quebec students mobilized against a 75\% tuition fee increase. In these two weekends, I saw the police act out in the interests of the capitalist state and repress peaceful protestors. I was even pepper-sprayed with a group of demonstrators the night a special law was passed in Quebec which made peaceful protests illegal. Witnessing this repression, and experiencing some of this repression myself, made the Marxist texts about the state's role in supporting the capitalist class' interests come to life. My beliefs in the need for a communist party to fight for reforms and ultimately, socialist revolution, became stronger. Since 2012, I have been a member of the Communist Party of Canada, which, along with the Young Communist League of Canada, is a small organization - but an active onewhich fights for free education, labour rights, against Canada and the USA going to war abroad, and for solidarity with Indigenous peoples, amongst other issues.

In general, Canadian and Chinese perspectives clash with respect to their opinion of socialism in China. The Canadian media, as well as the Canadian public, tend to be critical of communism in China, citing allegations of human rights violations and intrusive state interference in Chinese society, as exemplified by a recent internal government report discussing human rights in China (Blanchfield, 2017). However, the Government of China instead recognizes communism as the long-term goal for its society and holds that China is under the political and economic governance of market socialism (Kuhn, 2011). With the ongoing campaign by the Chinese Government to promote core socialist values within the Chinese population (Gow, 2016), it was interesting to learn more about how the political science curriculum portrays Chinese socialism in Chongqing, China.

China has made significant gains in development with its recent implementation of universal health insurance coverage (Yu, 2015) and lifting almost 800 million people out of poverty since the 1980s (Sanchez, 2017). According to a Pew Research Centre (2013) study, 82\% of the Chinese population believe children will be better off than their parents. These developmental gains and general optimism for the future in China amongst its population contradict broad Canadian perspectives of socialism in China.

I was excited to hear in Canada that China has been both reducing poverty and has plans to lessen the gap between the rich and poor. I also believe the projects of the last party congressto develop and consolidate the public sector-are positive for China (Xi, 2018). I am worried about the growing imperialist threats from the United States, the country's many military bases which surround China, the increasing tensions as a result of the trade war between the United States and China, as well as growing fearmongering within Western media regarding China's economic and political rise in the world. In this context, I was excited to hear the news that the Chinese government is increasing the number of compulsory Marxism courses in university and college.

\section{Research Questions: Politics Teacher's Political Perceptions}

This Mitacs Globalink research project explores how the middle school political science curriculum in China portrays Chinese socialism. My primary research questions were: (a) what are the perceptions of Chinese Socialism among Chinese political science teachers in Chongqing, 
China? and (b) what will the Chinese political science teachers I encounter have to say about the connection between recent developmental gains in China and China's socialist system? These questions were answered through a quasi-qualitative narrative structure that produced other observations about China's politics curriculum as well.

\section{Socialist Perspectives of China}

Unlike some Western Marxists, in general, I am supportive of the Communist Party of China and its role in improving living conditions. The late Domenico Losurdo (2016) argues that China underwent market reforms to close the gap between developed countries in the West and underdeveloped countries, including China. He also claims that this market reform does not mean China has restored capitalist leadership (Losurdo, 2016). Instead, China still is governed through the interests of the working class through the Communist Party of China. While market reforms have opened up China and capitalists have gained power in the economy, they have been shut out of formal political power (Losurdo, 2016).

On the other hand, another late Marxist philosopher whom I also have great respect forSamir Amin (2013) - argues that China is neither socialist or capitalist, but in a transitionary state, where the country can either become socialist or regress into capitalism. China is in a unique situation in world history because the total appropriation of farmer's land has not occurred, as is the case in all capitalist countries. For Amin (2013), China also has a large state capitalist sector that can either play a role in the transition to socialism or be further privatized, resulting in China becoming capitalist. He adds that class struggle will play a significant role during China's transitionary stage, and whether socialism wins out depends on which class force wins in China, the working class or the bourgeoisie (Amin, 2013).

I find both explanations of Chinese socialism to be much more compelling than academic Marxists who condemn China as much as the U.S. empire or condemn the foreign policy of China more than the exploitative foreign policy of western imperialism, including Canada's foreign policy. However, this paper will be influenced mostly by Amin's (2013) article because I think it is crucial for me to take a step back, not engage in the debate over whether China is socialist or not, but instead look as objectively as I can at China's politics and Marxist curriculum.

\section{Methods}

\section{Informal Discussions and In-Class Observations}

Dr. Shijing Xu and her research assistant, Yuhan Deng, gave me the opportunity to connect with professors at Southwest University (SWU) informally and through seminars, introductions by Marxist teaching candidates, and middle school classroom observation in Chongqing, China. I lived in an international dormitory on campus, with local schools, university students, and seminars located conveniently close to me through public transit. Thanks to receiving support from Mitacs, which Dr. Xu and Yuhan Deng helped me to secure, my travel, food, and residence stay was monetarily covered for the trip. 
For my research, I audited middle school political science classes at TJB Middle School. I also had the opportunity to review some politics classes at a secondary school in the Beibei district of Chongqing. I spoke with teacher candidates and professors about their socialist curriculum in political science classes, clarified any questions I had, and heard the opinions of individual students and teachers about their curriculum. I took notes of these observations as well. At the start of my trip, I also had the opportunity to attend some special seminars organized for the contingent from the University of Windsor. I found one workshop on "Understanding China - In View of History" by Dr. Y. W. to be particularly helpful. The findings of my project primarily come from the Southwest University seminars, observing middle school classrooms, and talking informally with political science teacher candidates as well as university political science professors.

\section{Interactions and Experiences}

\section{“Understanding China-In View of History” by Dr. Y. W. at Southwest University}

Dr. Y. W.'s lecture on China interested me in a few ways. It occurred near the beginning of our time in Southwest University, in early April. He discussed the general trend of Chinese education emphasizing the importance of unity in China in its 5,000-year history. At least in modern history, China emphasizes unity because of the imperialist attacks it faced, ranging from the opium wars to Japanese aggression. Unity in China is essential for maintaining its strength, sovereignty, and the right to self-determination as a nation. I believe unity still needs to be emphasized because of the continued threat from U.S. imperialism, which I have mentioned earlier. This lecture was also helpful for me because Dr. Y. W. stressed that, for China's Communist Party, China is a dictatorship of the proletariat which, if true, is a crucial condition of socialism being the primary system in China. It was also interesting to hear that Chinese historiography generally finds peasant uprisings to be uprisings which were positive and pushed China's development forward.

\section{Observations at Southwest University-Affiliated Middle and High School: Dynamic Lessons}

I observed some middle school political science classes at a joint middle school and high school in the Beibei District at the start of my trip. For my final three weeks, I changed placements from ZJY Primary School to TJB Middle School, where I am thankful I received the opportunity to observe history, politics, and English courses, as well as teach some combined history and English courses.

I attended a senior grade one politics class about governance in China. I received some translation for this class where students discussed a video about regulations on food prices in China. The teacher led a discussion on a recent event where protestors were not allowed into a meeting where government officials voted to raise the price of some food items, and the teacher asked students to reflect on the video. He talked about how it was a positive sign that the media discussed this contentious issue, and positive that the government was held accountable by journalists. However, he also considered the negative actions of the government being too formalistic and too bureaucratic. The teacher discussed with students the positive and negative aspects of government regulations on food prices. The teacher continued by talking with students 
about the advantages and disadvantages of living in the Beibei district, their local community. Finally, the teacher showed a video about the streamlining of social insurance in China to show the Chinese government is moving from a management government to a service government. From this lesson, I saw the teacher use class discussion to engage students, but the class was mostly lecture-based. This teacher also used real-life and local examples to help the course come to life.

I was later led to a discussion amongst politics teachers about their grade 10 curriculum. Here, one teacher did her best to interpret for me. I saw three teachers in this meeting have a debate about how to teach the curriculum about governance in China. Two teachers wanted to start the curriculum unit by discussing what they believed to be the basis of governance in China, the law. Another teacher argued that the basis of governance in China is its structure of democratic decision-making. I do not know the outcome of this debate, but I did see that the discussion was passionate yet respectful, and all the teachers remained friendly afterward. A friend of mine who was also present on the trip shared with me about other topics discussed during the meeting, including how much to teach from the textbook versus other sources. One teacher advocated to teach less from the textbook and use more personal experiences for students to learn about China's governance structure. The teachers also discussed the topic of China's treatment of ethnic minorities in comparison to issues of racism in the West, as well as issues of corruption in China compared to problems of corruption in the West. Finally, the teachers discussed how they would incorporate the new curriculum topic about the importance of sound environmental governance into their classroom.

It was interesting to see politics teachers from China working together to make sure they taught Senior 1 classes about governance in China in a similar way. At my first placement in Canada, my teacher complained it could be challenging to meet with other teachers in his department and coordinate curriculum. Perhaps, in Canada, some teachers are worried about being told what to teach and coordinating curriculum with their fellow teachers. Indeed, I too am worried about this situation as a future history teacher who plans to instruct many of my lessons from a Marxist perspective. I worry administrators will tell me my lessons are too radical or too antiCanadian or without balance, and I worry about feeling pressured to change my teaching philosophy as a result.

I have good reasons to be worried: in my third year of university studies, I taught a lesson to grade 10 students about repression by the Canadian state against social movements and racialized people in Canada. After this experience, a parent of a student called the teacher who invited me. The parent worked for the Canadian Security Intelligence Service (CSIS) and complained about the political content of my lesson.

\section{Observations at TJB Middle School: Trouble Understanding the Chongqing Dialect}

At TJB Middle school, I observed political science courses which discussed Taiwan, China's relationship with ethnic minorities and national autonomous regions, youth and the law, and other topics. However, it was difficult to understand any of the content for these classes. Teachers spoke in the Chongqing dialect, and the SWU students who translated for me had trouble understanding this dialect. 
The lessons were conducted entirely in lecture style. Students collectively answered questions, and sometimes the teacher gave students the answers to problems in their workbook. The students were to memorize their answers, and specifically the answers which the teacher told them were important. There were not many opportunities for student-led activities in these classes and lessons were taught through the textbook and in preparation for exams. This lecture-based teaching style conflicts with comments in the media made by a Marxist university professor (Wei, 2017) and comments from university students I met in Southwest University about the need for making students learn more actively about China's politics curriculum.

\section{Observations with University Students Via WeChat: Differences Between Canadian Civics Curriculum and China's Politics Curriculum}

I have remained in communication with two politics teacher candidates on WeChat (a Chinese social media platform). Both candidates attended the University of Windsor last fall and helped in answering my questions about the politics curriculum. One of them suggested I read the book "The Governance of China" by Xi Jinping to learn more about socialism with Chinese characteristics. She also sent me a brief description of the topics covered in the Chinese middle school and high school politics curriculum. Students need to take four compulsory courses: (a) Economy and Life, (b) Politics and Life, (c) Culture and Life, and (d) Philosophy and Life.

My most revealing conversation on WeChat with one of the teacher candidates, who had participated in an exchange at the University of Windsor with the Reciprocal Learning Program in 2017, occurred when she wrote this:

Can I ask you some questions? What's your major in university? Will you teach Marxism after graduation? When I was in Canadian high school, I found civics teachers only teach a little about socialism and communism. And once a teacher told the students that these systems aren't practical. So, if it's convenient, could you tell me most schools' attitude toward this system? And how do you feel about socialism? I am ready to accept the reality. (Chinese teacher candidate, personal communication, 2018)

From this message, we launched into a long conversation. Some of the main points I made are below:

Canadian civics classes follow a liberal ideology. Most of the teachers are hostile to socialism. I think some civics classes also give students too many open assignments where the western media manipulate students to believe negative things about other countries, including China. However, some other teachers support some political activism and are social democratic in political orientation. They encourage students to criticize some policies of capitalist governments like Canada and the USA. They encourage students to think critically and support activism in Canada that fights for worker's rights, struggles against racism, etc. 
These types of teachers are in the minority. They have some correct ideas but can easily be fooled to have the wrong idea. Some of these social democratic teachers take a strong anti-imperialist stance, but others can be tricked to support Canada and the USA's wars of aggression abroad. I'm rare for Canada because I support Marxism Leninism and support socialism and I am in the Communist Party of Canada. There are not many teachers like me in Canada. (Chinese teacher candidate, personal communication, 2018)

From my reply, we spoke more. The candidate revealed that in Windsor she witnessed her teacher talk about socialism and fascism as if they are the same thing, and we discussed how horrible an idea this is. She emphasized that she was happy I was working to stop the prejudice in schooling against China as well. I talked to her about issues in Canada, especially regarding the oppression of Indigenous peoples, and she was aware of this issue. Humbly, she answered me by writing:

Each country has their weak points. China also has many things we need to learn. And I found a fascinating thing; in maps, most countries prefer to put itself in the middle. So does China. But China never wants to be the center. (Chinese teacher candidate, personal communication, 2018)

I have noticed Chinese teacher candidates are very humble and very open to learning from other countries. The people here have learned the importance of peaceful diplomacy, including its top leaders, and the people have discovered an international approach to learning from different cultures. Another teacher candidate I talked to in 2018 while she was on exchange in Windsor told me that China does not consider playing an aggressive role or going to war abroad. She also said she had heard many stories about the imperialist interventions of the United States, but not of Canada. Indeed, in the eyes of the Chinese, Canada is seen as a great country, when in fact, Canadian imperialism often supports U.S. imperialism, exemplified by our leading role in the recent aggressive war against Libya.

\section{A Marxist Event: Ambitions to Promote Marxism}

Students organized an event about Marxism on May 5th to celebrate 200 years since the birth of Karl Marx. They showed videos, had posters and displays discussing Marx's achievements, and had the opportunity to write about what Karl Marx meant to them. A politics teacher candidate helped me to interpret some of the event. The Socialism with Chinese Characteristics student club organized the event well, but it seemed to be more of a drop-in event. There were too few people, but more than the Marxism event on the same day in my hometown of Guelph, Ontario, Canada. Students took photos of my friend and me as we talked about her club. Perhaps the students were surprised that I was there as a foreigner. 
The students gave me the opportunity to write about Karl Marx and to sign my name on a banner. I wrote: "Marx's ideas continue to inspire workers and oppressed people all over the world." My friend said what I wrote was "so nice."

I learned from my friend that her club also runs a WeChat page for students to learn more about Marxism with Chinese characteristics. Indeed, social media has a strong presence in China and Marxist departments are beginning to take seriously the need to meet students where they are at (Li, 2017) and promote Marxist education as well as core socialist values using social media. There is much competition on social media for these Marxist pages ( $\mathrm{Li}, 2017$ ).

\section{Meeting with Politics Teacher Candidates: Ambitions to Make Their Classrooms Dynamic}

Later, I met with another politics teaching candidate. It was an excellent first meeting, and she could speak English well because English is her minor. The meeting was informal, and I did not ask many questions about the curriculum. However, it was still informative for me to meet with her. We spoke about the war in Syria, and I could sense from her and other friends from China that many understand that the missiles launched by the United States and Britain were an act of aggression and against international law. They were worried about acts of aggression by the United States and would prefer that the United States and other countries use diplomatic methods to address international conflict. Instead of imperialist aggression, the United Nations should have investigated into who used chemical weapons in Syria. It seemed teachers were especially aware of global issues. Some people in Canada may not think critically about international conflict and realize that Canada supported the missile strikes in Syria by the United States.

Another topic I discussed with her was the relationship between China and the continent of Africa. I told her that it seems to me as though China is helping Africa to develop much more than the United States; the U.S. policy is to have transnational companies open up in Africa and exploit its people and resources. She said she believed that China is helping Africa too, and she believes China cares a lot about Africa in part because of the help the African nations gave to China when China joined the United Nations.

I also met with a second politics teacher candidate who has applied to come to Windsor for the Reciprocal Learning Program, (this was the same friend I met with to celebrate the birth of Karl Marx). At our first meeting, I spoke more than her because I was so excited to share with her my experiences as a Marxist in the West. I told her that, as a student, I have made it part of my task to fight for free education and against expensive tuition fees. I also said that I see it as a Marxists' role to fight for better working conditions for all workers. And finally, I see it as a critical task for Marxists in Canada to be internationalists who support socialist countries around the world, support struggles of national liberation around the world, and advocate against Western imperialist countries from going to war. I told her about the Quebec student strikes in 2012 and how they were a time when mass action by young people brought about positive results. She asked me if this protesting was effective. I said it was, because the protest stopped a $75 \%$ tuition fee increase in Quebec. Quebec has the lowest tuition fees in the country because of the higher level of student mobilization in that province. 
I learned a lot from this question about the effectiveness of protesting that was posed to me by the politics student candidate. I believe that her inquiry about whether the protests in Quebec against tuition fees were effective or not revealed a significant difference between Chinese Marxism and the Marxism I adhere to. Chinese Marxism emphasizes unity in society, while Marxism in Canada emphasizes class struggle. However, I do not think these differences are incompatible. It makes sense to me that Chinese Marxism emphasizes unity. China has a history of facing imperialist attacks from the Western world. As a united and stable country, China has prospered in its past, but when the country encountered the opium wars and Japanese aggression, for instance, China suffered at the hands of imperialism. In Canada, Marxists should play the role of enhancing the class struggle and the struggle against war, because unions should defend workers' rights in Canada, and because the peace movement must be improved to stop Canada or the United States from participating in more wars of aggression. Through this work by Marxists in Canada, we also hope to build unity between forces and peoples in Canada who want to create a peaceful world.

The politics teacher candidate also answered questions asked by me, including when I asked her what policies made her proud to be Chinese. She mentioned she is proud of China because it is safe to be in China due to its strict gun control laws. She also cited China's ban on drugs because she believes this is helpful to the life of a person. Finally, she mentioned China's poverty alleviation work and the government's foreign policy that advocates for peace. She also said she believes the Chinese system upholds the interests of workers, including actions by the Government of China to raise the starting point of personal income tax, establish medical protection and social protection, and have retirement ages of 55 for women and 60 for men.

I also learned more about Marxist curriculum. The politics student provided a written answer for me, and I have quoted her answer here:

In junior high schools and primary schools, we usually carry out ideological and moral education and rule of law education, mainly telling students what should be done and establishing moral values. And guide them in their growing psychological problems, such as love. In high school, we use two books to introduce the economic and philosophical part of Marxism and other two books about China's politics and Chinese culture. (Chinese teacher candidate, personal communication, 2018)

I stayed in touch with the two politics students whom I met in person, as I was surprised by some of the things they told me. One student said that the Chinese government and the Communist Party of China recognizes China as a classless society. She told me this after I said that I was teaching and observing classes at a working-class middle school. She responded that China does not recognize classes but instead recognizes different levels of income. I believe this is the wrong position for China to hold, and not a Marxist position to have. Classes still exist in China. Both capitalists and workers are in China, with different interests. I am worried that the interests of capitalists are being supported too much in China since the opening up to foreign markets after the Cultural Revolution, but I still believe that China is doing much to uphold the 
interests of workers by expanding social services and improving standards of living. It was also interesting for me to hear her say that China supports the interests of the whole Chinese population and not any particular class. I believe it is essential for China to uphold the interests of the Chinese nation, but also uphold the interests of workers, and do this explicitly.

I held a final meeting with two politics teacher candidates in my last two weeks in Chongqing. One student was the same student who hoped to go to Windsor as part of the Reciprocal Learning Program in the fall, and another student was a first-year politics student. During this meeting, I asked the following questions:

1. How will you structure your classes when you become a teacher?

2. What political issues will you allow students to debate?

3. What ideas about Marxism do you think are important for all students to know?

4. What points about Marxism does your curriculum focus on?

This meeting was fascinating, with one teacher candidate telling me that she hopes not to teach her courses with such a lecture-based strategy. Instead, she hopes to teach using more activities. However, she noted that graduate students at Southwest University, and administrators in Chinese schools where she may wish to eventually work, generally believe in the superiority of the lecturing model when it comes to teaching. She also answered for me what students can debate and what students cannot debate in the Chinese classroom. Students cannot debate major questions, like whether one should love their country, but other vital questions, like whether or not to reduce school fees, can be debated.

The most interesting point of our discussion came from her answer about what significant points students should know about Marxism. She answered that students must understand (a) the theory of surplus value, and that workers create value and they should be respected; (b) that people are important to China, and should be active in China's events; (c) that matter determines consciousness; (d) that everything is continually changing and developing, which means that you are not the same as one year ago, nor is China the same as even one minute ago; and (e) that Marxism should be used to understand, analyze, and solve problems.

\section{Discussions with Marxist Professors: Why Chinese Socialism is Supported by Most in China}

I met one Marxist professor by chance while playing basketball with him on campus. We set up a time to discuss politics, and I found him to be asking me more questions than I to him. He was fascinated to meet with a Marxist from Canada and asked me why Canadians seem to be okay with the fact that Canada's foreign policy aligns with the aggressive foreign policy of the United States. I tried to tell him that Canada does have a history of peaceful protests against war, including demonstrations against the U.S. war in Vietnam and the Gulf War in Iraq. However, the peace movement in Canada is at a low level of mobilization, with many Canadians tricked by the Responsibility to Protect (United Nations General Assembly, 2005) doctrine from our leaders, a doctrine that calls for aggressive intervention against authoritarian foreign governments - when instead the interventions are done in the interests of profit and imperialism. 
In my final week, I also had the privilege of talking with a Marxist professor who helps politics teacher candidates at SWU. He confirmed what I had learned earlier in my discussions with politics teacher candidates: middle school curriculum does not discuss Marxist theory as much as in high school and university, and the curriculum focuses more on citizenship education, which teaches students about the political roles of different sections of government, the role of individuals in education, philosophy based on materialism, economics in China, and law in China. The professor also informed me that the new politics curriculum in China would bring more variety to classroom activities instead of using only lectures. Many teachers only seem to lecture, and the professor told me that he thinks students are more engaged with teachers who can share interesting stories as they lecture and less engaged with teachers who outline theories and teach only using the textbook. When asked about the engagement of students in Marxism classes, he told me that students have less incentive to be engaged because studying Marxism does not result in high paying jobs.

Perhaps the most exciting conversation occurred when I asked this professor how Marxism courses tell students to support socialism in China. He answered that it is more important for people in China to support socialism using economic incentives. People should see the benefits of development, as well as the benefits of the reduction of poverty, and the reduction of the income gap in China under socialism. These benefits result in people supporting and upholding socialism as more than a slogan put forward by a leader of the Communist Party. He cited the Chinese dream as an initiative that results in the hard work of many Chinese people.

The professor also spoke about students from China who study abroad. From his experience, these students are more likely to come back to China and appreciate its socialist system. They are more critical of the issues they see in the Western countries they study in, while still appreciating these countries. They are also very likely to come back home to China for work. His comments align with some comments I have heard from Chinese teacher candidates. For instance, I heard one teacher candidate during my placement at TJB Middle School tell me that he used to think of the United States as superior to China, but now he appreciates China for being safer. He cited the lack of gun control laws in the United States compared to strict regulations in China as one of the reasons why China is safer.

The professor told me that he thinks a significant difference between Chinese Marxism and Western Marxism is that Chinese Marxism has taken on a less confrontational and more constructivist approach. Chinese Marxism now emphasizes development, and the Communist Party does not recognize classes in China but instead varying income levels for people.

I learned more from my meeting with this professor about why I received surprised reactions when I spoke with some Chinese students about issues in Canada. Chinese people seem to believe it is rude to talk negatively of another country, and instead focus on the positive sides of most countries. Many in China take pride in speaking positively about Western countries even after Western politicians and Western media propagandize negative views about China before sharing any positive things about the country. The Marxist professor connected China's respect and focus on the positive aspects of each country to China's respect for the right to selfdetermination of every nation. He told me that Canada is a great country, that it is almost a socialist 
country. I said to him that Canada is a capitalist country with a welfare state. The federal and provincial governments of Canada are eroding the system as we speak by privatizing public services.

\section{Final Thoughts: What We Should Learn from China's Politics Curriculum}

I began to learn about how China's political science curriculum portrays socialism in China from my observations, and I hope this will build knowledge and understanding of China's education sector from a cross-cultural perspective. A greater understanding of Chinese views of socialism and their relation to China's political science curriculum will foster a greater appreciation of educational similarities and differences between China and Canada. There is still much more work to do on this topic, and I hope to learn more about China's Marxist curriculum when I return to China to teach.

I think Marxist theory still provides a blueprint for changing the world. I understand Chinese Marxism's focus on unity over class struggle given the political context of the country; however, I agree with Amin's (2013) thesis that socialism will only prevail in China if the workers win against the wealthy capitalist owners of production in the class struggle currently underway in China. Politics teachers and departments will need to grapple with this reality in the future and talk about class struggle as well as unity as a dialectical relationship. Many politics students in China are siding with workers in conflicts, and are facing repression (Yang \& Liu, 2018), but these students are taking the right side if socialism is to prevail in China.

I am different from most Canadians whom Chinese people meet. I have found that Chinese politics students are especially interested in talking with me. They are surprised to hear me present Canada as a country I love but one with many issues. I try to educate some of my Chinese Marxist friends on issues of poverty in Canada, biases in Canadian media against China, as well as the effects of discrimination against Indigenous people. They are interested in learning about the issues in capitalist countries. They generally believe that socialism is right for China and has helped its development immensely. They also seem excited to learn more about issues in bourgeois democracies because they admit some Chinese people think liberal democracy is better than socialist democracy. Perhaps China needs to better educate its citizens on issues related to capitalist countries. Chinese students, and especially Marxist professors, should not have objectively false ideas that Canada is a socialist country.

I believe the most critical thing Ontario's education system can learn from China's political science curriculum is to be explicitly accepting of other countries' rights to self-determination. Canadian social science teachers should learn from China's perspective that it is essential to emphasize the positive aspects of each country instead of highlighting the negative issues of other countries. If teachers teach this, they will not disrespect the political systems of countries like China and Cuba by saying socialism is equivalent to fascism. By focusing on the positive aspects of other countries, civics teachers in Canada can also redirect their focus to encourage students to think more critically about issues within Canada instead of only analyzing issues in other countries, as if all countries have something to learn from Canada and Canada has nothing to gain from other 
countries. I am not saying that social science teachers should not be critical of other countries or should not allow students to be critical of other countries. Students and teachers can do this but must be wary of acting in a chauvinist manner by only focusing on issues in other countries. Teachers must not falsely say that Canada has a lot to teach other countries but nothing to learn from other countries. Indeed, if Ontario civics classes aim to teach students to be respectful of other cultures and nations, teachers need to allow students to understand perspectives that respect a nation's right to self-determination, not the propaganda of the imperialistic "responsibility to protect" doctrine currently prevalent in Canada.

\section{References}

Amin, S. (2013, March 1). China 2013. Monthly Review, 64(10). Retrieved from https://monthlyreview.org/2013/03/01/china-2013/

Blanchfield, M. (2017, July 12). Human rights in China going in 'negative direction': Internal Canadian government report. The Globe and Mail. Retrieved from https://beta.theglobeandmail.com

Gow, M. (2016). The core socialist values of the Chinese dream: towards a Chinese integral state. Critical Asian Studies, 49(1), 92-116. https://doi.org/10.1080/14672715.2016.1263803

Kuhn, R. L. (2011). How Chinese leaders think: The inside story of China's past, current and future leaders. Singapore: John Wiley \& Sons.

Li, H. (2017). Cultivation of college students' core socialist values from the perspective of new media. In Proceedings of the 3rd International Conference on Social Science and Management (ICSSM 2017). Lancaster, PA: DEStech Publications. Retrieved from http://dpiproceedings.com/index.php/dtssehs/article/view/10344

Losurdo, D. (2016). Has China turned to capitalism: Reflections on the transition from capitalism to socialism. International Critical Thought, 7(1), 15-31. https://doi.org/10.1080/21598282.2017.1287585

Pew Research Center. (2013). Economies of emerging markets better rated during difficult times. Retrieved from http://www.pewglobal.org/files/2013/05/Pew-Global-Attitudes-Economic-ReportFINAL-May-23-20131.pdf

Sanchez, C. (2017, December 7). From local to global: China's role in global poverty reduction and the future of development. The World Bank News. Retrieved from https://www.worldbank.org/en/news/speech/2017/12/07/from-local-to-global-china-role-globalpoverty-reduction-future-of-development

United Nations General Assembly. (2005). 2005 World summit outcome. Retrieved from http://www.globalr2p.org/media/files/wsod_2005.pdf

Wei, X. (2017, July 23). Full Marx for creativity: Reforming political education in China. Sixth Tone. Retrieved from http://www.sixthtone.com/news/1000561/full-marx-for-creativity-reforming-politicaleducation-in-china

Xi, J. (2017, October 18). Secure a decisive victory in building a moderately prosperous society in all respects and strive for the great success of socialism with Chinese characteristics for a new era. China Daily. Retrieved from http://www.chinadaily.com.cn/china/19thcpcnationalcongress/2017$\underline{11 / 04 / \text { content } 34115212 . h t m}$ 
Xu, S., \& Connelly, F. M. (2017). Reciprocal learning between Canada and China in teacher education and school education: Partnership studies of practice in cultural context. Frontiers of Education in China, 12(2), 135-150. https://doi.org/10.1007/s11516-017-0013-6

Yang, Y., \& Liu, Xinning. (2017, September 23). Peking University threatens to close down society. Financial Times. Retrieved from https://www.ft.com/content/ccab09aa-bdc2-11e8-8274$\underline{55 \mathrm{~b} 72926558 \mathrm{f}}$

$\mathrm{Yu}, \mathrm{H}$. (2015). Universal health insurance coverage for 1.3 billion people: What accounts for China's Success? Health Reform Monitor, 119, 1145-1152. https://doi.org/10.1016/j.healthpol.2015.07.008

$\sqrt{\pi}$ 